\title{
EFIKASI HERBISIDA PARAKUAT DIKLORIDA TERHADAP PERTUMBUHAN GULMA DAN TANAMAN SERTA HASIL KEDELAI (Glycine max L. Merr)
}

\section{THE EFFICATION OF HERBICIDE PARACUATE DICLORIDE ON THE GROWTH OF WEEDS AND SOYBEAN PLANT AND PRODUCTS (Glycine max L. Merr)}

\author{
Gangga Prastita Sari*, Herry Susanto, Kuswanta Futas Hidayat, dan Hidayat Pujisiswanto \\ Jurusan Agroteknologi Fakultas Pertanian Universitas Lampung \\ Jalan Prof. Dr. soemantri Brojonegoro No.1 Bandar Lampung 35145 \\ *E-mail: Ganggaprastitasari16@gmail.com
}

\begin{abstract}
The presence of weeds in soybean cultivation causes a decrease in quality and production. Therefore we need a management action, namely weed control. One method of controlling weeds is chemically using herbicides. The herbicide used in this study was the herbicide paraquat dichloride. The herbicide is contact in nature so it is expected to quickly control weeds. This study aims to determine the dose of herbicide paraquat dichloride which is effective in controlling weeds on soybean cultivation, to determine whether there has been a change in weed composition due to the application of herbicide paraquat dichloride, and to determine whether there is phytotoxicity and inhibition of growth and yield of soybean due to the application of herbicide paraquat dichloride. The research was conducted in the land of farmers in Pemanggilan Natar District, South Lampung Regency and the Weed Laboratory of the Faculty of Agriculture, University of Lampung from February to May 2019. The study used a randomized block design (RBD) with four replications and six treatments, namely the herbicide paraquat dichloride dose of $405 \mathrm{~g} / \mathrm{ha}, 540 \mathrm{~g} / \mathrm{ha}, 675 \mathrm{~g} / \mathrm{ha}, 810 \mathrm{~g} / \mathrm{ha}$, manual weeding and control. Homogeneity of various data was tested by Bartlett's test, data additivity was tested by Tukey's test, and mean differences were tested with Least Significant Difference (LSD) at the 5\% level. The results showed that: Paraquat dichloride herbicide dose of 405-810 $\mathrm{g} / \mathrm{ha}$ was effective in controlling total weeds, broad leaf weeds, grass class weeds and dominant weeds (Croton hirtus, Mimosa invisa, Rottboellia exaltata, and Synedrella nodiflora) in the soybean plant area up to 6 week after application. The herbicide paraquat dichloride caused changes in weed composition between 29-49\% at 3 weeks after application and 23-38\% at 6 weeks after application. The application of the herbicide paraquat dichloride at a dose of $405-810 \mathrm{~g} / \mathrm{ha}$ caused mild phytotoxicity with a toxicity range of 5-20\%, a dose of 405-810 $\mathrm{g} / \mathrm{ha}$ did not inhibit growth and soybean production was lower in herbicide treatment doses of $405-675 \mathrm{~g} / \mathrm{ha}$.
\end{abstract}

Keywords: Weeds, herbicides, soybeans, paraquat dichloride

\begin{abstract}
ABSTRAK
Keberadaan gulma pada lahan budidaya tanaman kedelai menyebabkan terjadinya penurunan mutu dan produksi. Oleh karena itu diperlukan suatu tindakan pengelolaan yaitu pengendalian gulma. Salah satu metode pengendalian gulma adalah secara kimiawi menggunakan herbisida. Herbisida yang digunakan dalam penelitian ini adalah
\end{abstract}


herbisida parakuat diklorida. Herbisida tersebut bersifat kontak sehingga diharapkan cepat dalam mengendalikan gulma. Penelitian bertujuan untuk mengetahui dosis herbisida parakuat diklorida yang efektif dalam mengendalikan gulma pada lahan budidaya tanaman kedelai, mengetahui apakah terjadi perubahan komposisi gulma akibat aplikasi herbisida parakuat diklorida, serta mengetahui apakah terjadi fitotoksisitas dan penghambatan pertumbuhan serta hasil tanaman kedelai akibat aplikasi herbisida parakuat diklorida. Penelitian dilakukan di lahan petani Desa Pemanggilan, Kecamatan Natar, Kabupaten Lampung Selatan dan Laboratorium Gulma Fakultas Pertanian Universitas Lampung mulai bulan Februari hingga Mei 2019. Penelitian menggunakan Rancangan Acak Kelompok (RAK) dengan empat ulangan dan enam perlakuan yaitu herbisida parakuat diklorida dosis $405 \mathrm{~g} / \mathrm{ha}, 540 \mathrm{~g} / \mathrm{ha}$, $675 \mathrm{~g} / \mathrm{ha}, 810 \mathrm{~g} / \mathrm{ha}$, penyiangan manual, dan kontrol. Homogenitas ragam data diuji dengan uji Bartlett, additivitas data diuji dengan uji Tukey, dan perbedaan nilai tengah diuji dengan uji Beda Nyata Terkecil (BNT) pada taraf 5 \%. Hasil penelitian menunjukkan bahwa: Herbisida parakuat diklorida dosis 405-810 g/ha efektif mengendalikan gulma total, gulma golongan daun lebar, gulma golongan rumput serta gulma dominan (Croton hirtus, Mimosa invisa, Rottboellia exaltata, dan Synedrella nodiflora)di areal tanaman kedelai hingga 6 MSA. Herbisida parakuat diklorida menyebabkan perubahan komposisi gulma antara 29-49\% pada 3 MSA dan 23-38\% pada 6 MSA. Aplikasi herbisida parakuat diklorida dosis $405-810 \mathrm{~g} /$ ha menyebabkan fitotoksisitas dalam skala ringan dengan rentang toksisitas 5-20\%, dosis 405-810 g/ha tidak menghambat pertumbuhan dan produksi kedelai lebih rendah pada perlakuan herbisida dosis $405-675 \mathrm{~g} / \mathrm{ha}$.

Kata kunci: Gulma, herbisida, kedelai, parakuat diklorida.

\section{PENDAHULUAN}

Menurut data Badan Pusat Statistik (BPS) (2015), produksi kedelai di Indonesia dari tahun 20112015 mengalami fluktuasi namun di tahun 2015 mengalami peningkatan produksi dari tahun 2014 sebesar 954.997 ribu ton menjadi 963.183 ribu ton. Salah satu kendala dalam membudidayakan tanaman kedelai yaitu kehadiran gulma.

Pengendalian gulma pada tanaman kedelai di Indonesia umumnya dilakukan secara manual, namun metode pengendalian tersebut masih dibatasi oleh ketersediaan tenaga kerja, biaya, waktu dan luasan areal pertanaman. Oleh karena itu petani cenderung menggunakan pengendalian gulma secara kimiawi dengan menggunakan herbisida. Herbisida parakuat diklorida merupakan herbisida kontak, non selektif dan aktif pada bagian tanaman yang berwarna hijau. Dalam penelitian ini akan dinilai bagaimana efektivitas herbisida parakuat diklorida pada berbagai dosis untuk mengendalikan gulma pada lahan budidaya tanaman kedelai dan apakah aplikasi herbisida parakuat diklorida pada lahan budidaya tanaman kedelai mengakibatkan terjadinya perubahan komposisi jenis gulma sehingga dapat diketahui daya kendali herbisida parakuat diklorida terhadap pertumbuhan gulma dan tanaman serta tingkat toksisitasnya pada tanaman kedelai.

\section{BAHAN DAN METODE}

Penelitian ini dilaksanakan pada bulan Februari hingga Mei 2019 di lahan petani Desa Pemanggilan, Kecamatan Natar, Kabupaten Lampung Selatan dan Laboratorium Gulma Fakultas Pertanian Universitas Lampung. Bahan yang digunakan adalah benih kedelai varietas Argomulyo, herbisida Gramoxone 135 SL 
(parakuat diklorida $135 \mathrm{~g} /$ 1), air, pupuk Urea, SP-36 dan $\mathrm{KCl}$, cat kayu, patok bambu dan kantung kertas. Sedangkan alat - alat yang digunakan adalah alat semprot punggung semi otomatis, nozzel T-jet warna kuning, gelas ukur, ember, ruber bulb, arit, cangkul, meteran, kuas, oven, timbangan digital, dan kuadran besi berukuran 0,5 $\mathrm{m}$ x 0,5 $\mathrm{m}$ dan sungkup nozzel.

Penelitian menggunakan rancangan acak kelompok (RAK) dengan 6 perlakuan dan 4 ulangan, yaitu herbisida parakuat diklorida dosis 405, 540, 675 dan $810 \mathrm{~g} /$ ha; penyiangan manual, dan kontrol. Satuan percobaan terdiri atas 24 petak percobaan masingmasing berukuran $3 \mathrm{~m}$ x $5 \mathrm{~m}$ dan jarak antar petak 0,5 $\mathrm{m}$. Volume semprot yang digunakan adalah $466 \mathrm{l} / \mathrm{ha}$. Herbisida diaplikasikan saat pagi hari pada tanaman kedelai yang berumur 21 hari setelah tanam. Pengamatan gulma dilakukan pada 3 dan 6 minggu setelah aplikasi (MSA) dengan 2 titik pengambilan yang berbeda disetiap pengamatan, menggunakan kuadran berukuran $0,5 \mathrm{~m}$ x 0,5 m. Gulma kemudian dipilah berdasarkan spesiesnya lalu dioven selama $2 \mathrm{x}$ 24 jam dengan suhu $80^{\circ} \mathrm{C}$ dan ditimbang.

Pengamatan meliputi data bobot kering gulma (gulma total, gulma pergolongan, dan gulma dominan) digunakan untuk menghitung nilai SDR (Summed Dominance Ratio), koefisien komunitas, dan persen penekanan. Selain itu diamati juga fitotoksisitas tanaman pada saat 1, 3, 5 dan 7 HSA. Pengamatan fitotoksisitas tanaman dinilai secara visual dengan metode skoring ( Direktorat Pupuk dan Pestisida, 2012). Pengamatan pertumbuhan sertahasil kedelai meliputi tinggi tanaman diamati dengan cara mengukur tinggi tanaman dari pangkal batang hingga titik tumbuh, jumlah cabang tanaman kedelai diamati berdasarkan seluruh cabang yang terbentuk pertanaman sampel, pengamatan jumlah bunga dilakukan pada saat bunga pertama muncul sampai tanaman tidak lagi menghasilkan bunga (selama 2 minggu). Pengamatan persentase bunga jadi polong dilakukan pada 2 tahap pengamatan, tahap pertama pengamatan dilakukan penghitungan jumlah bunga tanaman sampel, pada tahap kedua pengamatan dilanjutkan dengan penghitungan jumlah polong per tanaman sampel pada saat panen, kemudian dianalisis persentase bunga jadi polong berdasarkan pengamatan dengan satuan persen (\%) dengan rumus :

Persen bunga jadi polong $=$
$\frac{\sum \text { polong yang terbentuk }}{\sum \text { bunga yang terbentuk }} \times 100 \%$,

pengamatan jumlah polong isi pertanaman sampel dihitung berdasarkan seluruh polong bernas yang muncul pada tanaman sampel pada saat panen, bobot biji 100 butir diamati dengan menimbang 100 butir kedelai dari petak hasil dan diulang sebanyak 3 kali penimbangan. Bobot hasil biji kedelai kering diambil pada petak panen berukuran $2 \mathrm{~m} \times 2 \mathrm{~m}$ yang diambil saat panen dan dikonversi pada bobot butir kedelai dengan kadar air simpan $14 \%$ dengan menggunakan rumus:

$$
\text { KA } 14 \%=\frac{(100-\text { KATerukur })}{(100-14)} \mathrm{x}
$$

bobot kering berangkasan kedelai diamati dengan menimbang brangkasan kering terhadap tanaman sampel pada saat panen. Pengeringan dilakukan menggunakan oven dengan suhu $80^{\circ} \mathrm{C}$ selama 2 × 24 jam. 
Homogenitas ragam diuji dengan Uji Barlet, additivitas data diuji dengan Uji Tukey dan perbedaan nilai tengah diuji dengan Uji Beda Nyata Terkecil(BNT) pada taraf $5 \%$.

\section{HASIL DAN PEMBAHASAN}

\section{Bobot Kering Gulma}

Tabel 1 menunjukkan bahwa herbisida parakuat diklorida pada dosis $405-810 \mathrm{~g} /$ ha efektif mengendalikan gulma total pada 3 - 6 MSA. Hal tersebut juga sejal an dengan hasil penelitian Perkasa et al. (2016) yang menyatakan bahwa herbisida parakuat diklorida efektifmenekan pertumbuhan gulma total pada lahan budidaya tanaman kedelai hingga 6 MSA dengan bobot kering gulma tidak berbeda dengan penyiangan manual. Herbisida parakuat diklorida 405-810 g/ha mampu menekan pertumbuhan gulma total sebesar 77 $89 \%$ pada 3 MSA dan $77-83 \%$ pada 6 MSA.

Hasil analisis vegetasi spesies gulma golongan rumput yang ditemukan pada petak percobaan yaitu Axonopus compressus, Brachiaria pasphaloides, Imperata cylindrica dan Rottboellia exaltata. Pada 3 MSA herbisida parakuat diklorida dosis $405 \mathrm{~g} / \mathrm{ha}$ menunjukkan daya kendali yang berbeda dengan penyiangan manual (Tabel 2). Adnan (2012) menyatakan bahwa tingginya bobot kering gulma

Tabel 1. Pengaruh herbisida Parakuat diklorida terhadap bobot kering gulma total

\begin{tabular}{|c|c|c|c|c|}
\hline \multirow{2}{*}{ Perlakuan } & \multicolumn{2}{|c|}{$3 \mathrm{MSA}$} & \multicolumn{2}{|c|}{$6 \mathrm{MSA}$} \\
\hline & Asli & $\sqrt{ } \sqrt{ }(X+0,5)$ & Asli & $\sqrt{ }(X+0,5)$ \\
\hline & & $\ldots \ldots \ldots . .(\mathrm{g} / 0$ & & \\
\hline Parakuat diklorida $405 \mathrm{~g} / \mathrm{ha}$ & 8,96 & $1,68 \mathrm{~b}$ & 38,84 & $6,11 \mathrm{~b}$ \\
\hline Parakuat diklorida $540 \mathrm{~g} / \mathrm{ha}$ & 5,95 & $1,57 \mathrm{bc}$ & 29,26 & $5,36 \mathrm{bc}$ \\
\hline Parakuat diklorida $675 \mathrm{~g} / \mathrm{ha}$ & 9,03 & $1,66 \mathrm{bc}$ & 40,48 & $6,36 \mathrm{~b}$ \\
\hline Parakuat diklorida $810 \mathrm{~g} / \mathrm{ha}$ & 4,26 & $1,40 \mathrm{bc}$ & 30,71 & $5,40 \mathrm{bc}$ \\
\hline Penyiangan manual & 2,46 & $1,22 \mathrm{c}$ & 16,46 & $4,01 \mathrm{c}$ \\
\hline Kontrol & 37,98 & 2,48 a & 170,95 & $13,08 \mathrm{a}$ \\
\hline BNT $5 \%$ & & 0,45 & & 1,47 \\
\hline
\end{tabular}

Keterangan : Nilai tengah pada setiap kolom yang diikuti huruf yang sama tidak berbeda nyata menurut uji BNT pada taraf $5 \%$.

Tabel 2. Pengaruh herbisida Parakuat diklorida terhadap bobot kering gulma golongan rumput

\begin{tabular}{|c|c|c|c|c|}
\hline \multirow{2}{*}{ Perlakuan } & \multicolumn{2}{|c|}{$3 \mathrm{MSA}$} & \multicolumn{2}{|c|}{6 MSA } \\
\hline & Asli & $\sqrt{ } \sqrt{ }(X+0.5)$ & Asli & $\sqrt{ } \sqrt{ }(X+0.5)$ \\
\hline & & .................. $(\mathrm{g}$ & & \\
\hline Parakuat diklorida $405 \mathrm{~g} / \mathrm{ha}$ & 2,97 & $1,33 \mathrm{~b}$ & 17,03 & $1,83 \mathrm{~b}$ \\
\hline Parakuat diklorida $540 \mathrm{~g} / \mathrm{ha}$ & 2,45 & $1,26 \mathrm{bc}$ & 13,98 & $1,76 b$ \\
\hline Parakuat diklorida $675 \mathrm{~g} / \mathrm{ha}$ & 1,77 & $1,16 \mathrm{bc}$ & 14,35 & $1,88 \mathrm{~b}$ \\
\hline Parakuat diklorida $810 \mathrm{~g} / \mathrm{ha}$ & 0,98 & $1,06 \mathrm{bc}$ & 11,72 & $1,85 \mathrm{~b}$ \\
\hline Penyiangan manual & 0,35 & $0,92 \mathrm{c}$ & 4,87 & $1,42 \mathrm{~b}$ \\
\hline Kontrol & 9,50 & $1,72 \mathrm{a}$ & 66,17 & $1,85 \mathrm{a}$ \\
\hline BNT $5 \%$ & & 0,35 & & 0,62 \\
\hline
\end{tabular}

Keterangan : Nilai tengah pada setiap kolom yang diikuti huruf yang sama tidak berbeda nyata menurut uji BNT pada taraf $5 \%$. 
disebabkan oleh dosis herbisida yang masih rendah sehingga akan berpengaruh terhadap rendahnya daya kendali herbisida tersebut. Herbisida parakuat diklorida 405-810 g/ha mampu menekan pertumbuhan gulma golongan rumput sebesar $69-90 \%$ pada $3 \mathrm{MSA}$ dan $74-82 \%$ pada 6 MSA.

Hasil analisis vegetasi yang dilakukan pada petak percobaan didapat beberapa jenis gulma golongan daun lebar, diantaranya adalah Asystasia gangetica, Borreria alata, Borreria laevis, Calopogonium mucunoides, Chromolaena odorata, Cleome rutindosperma, Commelina benghalensis, Centrocema pubescens, Croton hirtus, Euphorbia geniculata, Ipomoea triloba, Mimosa invisa, Phyllanthus niruri, Porophyllum ruderale, Praxelis climatidea, Spigelia anthelmia, dan Synedrella nodiflora. Tabel 3 menunjukkan bahwa herbisida parakuat diklorida dosis 405 - $810 \mathrm{~g} / \mathrm{ha}$ mampu mengendalikan gulma golongan daun lebar pada 3-6 MSA. Sarbino dan Syahputra (2012) menyatakan bahwa herbisida pasca tumbuh parakuat diklorida dosis 414 $828 \mathrm{~g} /$ ha efektif dalam mengendalikan gulma daun lebar. Herbisida parakuat diklorida dosis $405-810 \mathrm{~g} / \mathrm{ha}$ menekan pertumbuhan gulma golongan daun lebar sebesar $80-89 \%$ pada 3 MSA, dan $79-82 \%$ pada 6 MSA. Gulma dominan yang terdapat pada petak

Tabel 3. Pengaruh herbisida Parakuat diklorida terhadap bobot kering gulma golongan daun lebar

\begin{tabular}{|c|c|c|c|c|}
\hline \multirow{2}{*}{ Perlakuan } & \multicolumn{2}{|c|}{$3 \mathrm{MSA}$} & \multicolumn{2}{|c|}{6 MSA } \\
\hline & Asli & $\sqrt{ } \sqrt{ }(X+0,5)$ & Asli & $\sqrt{ }(X+0,5)$ \\
\hline & \multicolumn{4}{|c|}{$\ldots \ldots \ldots \ldots \ldots \ldots \ldots \ldots\left(\mathrm{g} / 0,5 \mathrm{~m}^{2)} \ldots \ldots\right.$} \\
\hline Parakuat diklorida $405 \mathrm{~g} / \mathrm{ha}$ & 5,98 & $1,49 \mathrm{~b}$ & 21,66 & $4,68 \mathrm{~b}$ \\
\hline Parakuat diklorida $540 \mathrm{~g} / \mathrm{ha}$ & 3,50 & $1,39 \mathrm{~b}$ & 15,24 & $3,83 \mathrm{bc}$ \\
\hline Parakuat diklorida $675 \mathrm{~g} / \mathrm{ha}$ & 7,26 & $1,58 \mathrm{~b}$ & 26,13 & $5,14 \mathrm{~b}$ \\
\hline Parakuat diklorida $810 \mathrm{~g} / \mathrm{ha}$ & 3,27 & $1,25 \mathrm{~b}$ & 18,98 & $4,00 \mathrm{bc}$ \\
\hline Penyiangan manual & 2,43 & $1,20 \mathrm{~b}$ & 10,36 & $3,17 \mathrm{c}$ \\
\hline Kontrol & 29,42 & $2,33 \mathrm{a}$ & 103,33 & $10,17 \mathrm{a}$ \\
\hline BNT $5 \%$ & & 0,49 & & 67 \\
\hline
\end{tabular}

Keterangan : Nilai tengah pada setiap kolom yang diikuti huruf yang sama tidak berbeda nyata menurut uji BNT pada taraf 5\%.

Tabel 4. Pengaruh herbisida Parakuat diklorida terhadap bobot kering gulma dominan Croton hirtus

\begin{tabular}{|c|c|c|c|c|}
\hline \multirow{2}{*}{ Perlakuan } & \multicolumn{2}{|c|}{$3 \mathrm{MSA}$} & \multicolumn{2}{|c|}{$6 \mathrm{MSA}$} \\
\hline & Asli & $\sqrt{ }(X+0,5)$ & Asli & $\sqrt{ } \sqrt{ } \sqrt{ }(X+0,5)$ \\
\hline & \multicolumn{4}{|c|}{$\ldots \ldots \ldots \ldots\left(\mathrm{g} / 0,5 \mathrm{~m}^{2}\right) \ldots \ldots \ldots$} \\
\hline Parakuat diklorida $405 \mathrm{~g} / \mathrm{ha}$ & 0,17 & $0,81 \mathrm{~b}$ & 1,93 & $1,01 \mathrm{~b}$ \\
\hline Parakuat diklorida $540 \mathrm{~g} / \mathrm{ha}$ & 0,00 & $0,70 \mathrm{~b}$ & 0,12 & $0,93 \mathrm{~b}$ \\
\hline Parakuat diklorida $675 \mathrm{~g} / \mathrm{ha}$ & 0,00 & $0,70 \mathrm{~b}$ & 0,00 & $0,91 \mathrm{~b}$ \\
\hline Parakuat diklorida $810 \mathrm{~g} / \mathrm{ha}$ & 0,20 & $0,81 \mathrm{~b}$ & 0,18 & $0,94 \mathrm{~b}$ \\
\hline Penyiangan manual & 0,00 & $0,70 \mathrm{~b}$ & 0,82 & $1,00 \mathrm{~b}$ \\
\hline Kontrol & 1,85 & $1,51 \mathrm{a}$ & 12,11 & $1,29 \mathrm{a}$ \\
\hline BNT $5 \%$ & & 0,21 & & 0,19 \\
\hline
\end{tabular}

Keterangan : Nilai tengah pada setiap kolom yang diikuti huruf yang sama tidak berbeda nyata menurut uji BNT pada taraf 5\%. 
percobaan adalah gulma dari golongan daun lebar yaitu gulma Croton hirtus, Mimosa invisa, Synedrella nodiflora, dan gulma golongan rumput yaitu Rottboellia exaltata Penentuan gulma dominan dilihat dari nilai SDR (Summed Domminace Ratio) tertinggi pada perlakuan kontrol 3 dan 6 MSA. Herbisida parakuat diklorida dosis $405-810 \mathrm{~g} /$ ha efektif mengendalikan gulma C. hirtus, M. Invisa, $R$. exaltata, dan S.nodiflora dengan daya kendali yang tidak berbeda antardosis dan penyiangan manual. Umiyati et al. (2019) menyatakan bahwa herbisida parakuat diklorida mampu mengendalikan pertumbuhan gulma S. nodiflora hingga 5 MSA. Herbisida parakuat diklorida dosis $405-810 \mathrm{~g} /$ ha menekan pertumbuhan gulma C. hirtus sebesar $91-89 \%$ pada 3 MSA, dan $84-100 \%$ pada 6 MSA, menekan pertumbuhan gulma $M$. invisa sebesar $92-98 \%$ pada 3 MSA, dan $85-88 \%$ pada 6 MSA, menekan pertumbuhan gulma $R$. exaltata sebesar $75-89 \%$ pada 3 MSA, dan $71-81 \%$ pada 6 MSA, dan menekan pertumbuhan gulma Synedrella nodiflora sebesar 80 - $87 \%$ pada 4 MSA, dan $76-67 \%$ pada 6 MSA.

\section{Komposisi Gulma}

Hasil penelitian menunjukkan bahwa pada 3 dan 6 MSA perlakuan herbisida parakuat diklorida dosis $405-810 \mathrm{~g} /$ ha menyebabkan terjadinya

Tabel 5. Pengaruh herbisida Parakuat diklorida terhadap bobot kering gulma dominan Mimosa invisa

\begin{tabular}{|c|c|c|c|c|}
\hline \multirow{2}{*}{ Perlakuan } & $3 \mathrm{MSA}$ & \multicolumn{3}{|c|}{$6 \mathrm{MSA}$} \\
\hline & Asli & $\sqrt{ } \sqrt{ }(x+0,5)$ & Asli & $\sqrt{ } \sqrt{ } \sqrt{ }(x+0,5)$ \\
\hline & & $\ldots \ldots \ldots .(\mathrm{g} / 0,5$ & 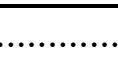 & \\
\hline Parakuat diklorida $405 \mathrm{~g} / \mathrm{ha}$ & 0,17 & $0,90 \mathrm{~b}$ & 2,40 & $1,06 \mathrm{~b}$ \\
\hline Parakuat diklorida $540 \mathrm{~g} / \mathrm{ha}$ & 0,25 & $0,92 \mathrm{~b}$ & 2,86 & $1,04 \mathrm{~b}$ \\
\hline Parakuat diklorida $675 \mathrm{~g} / \mathrm{ha}$ & 0,55 & $0,98 \mathrm{~b}$ & 0,91 & $1,01 \mathrm{~b}$ \\
\hline Parakuat diklorida $810 \mathrm{~g} / \mathrm{ha}$ & 0,50 & $0,85 \mathrm{~b}$ & 0,82 & $1,00 \mathrm{~b}$ \\
\hline Penyiangan manual & 0,00 & $0,84 \mathrm{~b}$ & 0,00 & $0,91 \mathrm{~b}$ \\
\hline Kontrol & 2,08 & $1,23 \mathrm{a}$ & 16,08 & $1,41 \mathrm{a}$ \\
\hline BNT $5 \%$ & & 0,18 & & 0,20 \\
\hline
\end{tabular}

Keterangan : Nilai tengah pada setiap kolom yang diikuti huruf yang sama tidak berbeda nyata menurut uji BNT pada taraf 5\%.

Tabel 6. Pengaruh herbisida Parakuat diklorida terhadap bobot kering gulma dominan Rottboellia exaltata

\begin{tabular}{|c|c|c|c|c|}
\hline \multirow[t]{2}{*}{ Perlakuan } & $3 \mathrm{MSA}$ & \multicolumn{3}{|c|}{$6 \mathrm{MSA}$} \\
\hline & Asli & $\sqrt{ } \sqrt{ }(x+0,5)$ & Asli & $\sqrt{ } \sqrt{ }(x+0,5)$ \\
\hline & \multicolumn{4}{|c|}{$\ldots \ldots \ldots \ldots\left(\mathrm{g} / 0,5 \mathrm{~m}^{2}\right) \ldots \ldots \ldots \ldots$} \\
\hline Parakuat diklorida $405 \mathrm{~g} / \mathrm{ha}$ & 1,90 & $1,17 \mathrm{~b}$ & 16,08 & $1,33 \mathrm{~b}$ \\
\hline Parakuat diklorida $540 \mathrm{~g} / \mathrm{ha}$ & 1,52 & $1,11 \mathrm{~b}$ & 13,52 & $1,29 \mathrm{~b}$ \\
\hline Parakuat diklorida $675 \mathrm{~g} / \mathrm{ha}$ & 1,40 & $1,06 \mathrm{~b}$ & 13,03 & $1,29 \mathrm{~b}$ \\
\hline Parakuat diklorida $810 \mathrm{~g} / \mathrm{ha}$ & 0,82 & $1.02 \mathrm{~b}$ & 11,52 & $1,36 \mathrm{~b}$ \\
\hline Penyiangan manual & 0,00 & $0,84 \mathrm{~b}$ & 4,50 & $1,17 \mathrm{~b}$ \\
\hline Kontrol & 7,50 & $1,65 \mathrm{a}$ & 59,80 & $1,66 \mathrm{a}$ \\
\hline BNT $5 \%$ & & 0,36 & & 0,28 \\
\hline
\end{tabular}

Keterangan : Nilai tengah pada setiap kolom yang diikuti huruf yang sama tidak berbeda nyata menurut uji BNT pada taraf $5 \%$. 
Tabel 7. Pengaruh herbisida Parakuat diklorida terhadap bobot kering gulma dominan Synedrella nodiflora

\begin{tabular}{|c|c|c|c|c|}
\hline \multirow{2}{*}{ Perlakuan } & \multicolumn{2}{|c|}{3 MSA } & \multicolumn{2}{|c|}{6 MSA } \\
\hline & Asli & $\sqrt{ } \sqrt{ } \sqrt{ }(X+0,5)$ & Asli & $\sqrt{ } \sqrt{ }(X+0,5)$ \\
\hline & & ….............. (g/0, & & \\
\hline Parakuat diklorida $405 \mathrm{~g} / \mathrm{ha}$ & 4,02 & $1,09 \mathrm{~b}$ & 7,90 & $1,59 \mathrm{~b}$ \\
\hline Parakuat diklorida $540 \mathrm{~g} / \mathrm{ha}$ & 0,97 & $1,02 \mathrm{~b}$ & 5,52 & $1,53 \mathrm{~b}$ \\
\hline Parakuat diklorida $675 \mathrm{~g} / \mathrm{ha}$ & 5,45 & $1,14 \mathrm{~b}$ & 9,65 & $1,70 \mathrm{~b}$ \\
\hline Parakuat diklorida $810 \mathrm{~g} / \mathrm{ha}$ & 2,60 & $1,06 \mathrm{~b}$ & 10,92 & $1,74 \mathrm{~b}$ \\
\hline Penyiangan manual & 0,40 & $0,96 \mathrm{~b}$ & 6,46 & $1,50 \mathrm{~b}$ \\
\hline Kontrol & 20,0 & $1,44 \mathrm{a}$ & 33,10 & $2,38 \mathrm{a}$ \\
\hline BNT $5 \%$ & & 0,24 & & 0,55 \\
\hline
\end{tabular}

Keterangan : Nilai tengah pada setiap kolom yang diikuti huruf yang sama tidak berbeda nyata menurut uji BNT pada taraf 5\%.

Tabel 8. Pengaruh herbisida parakuat diklorida terhadap koefisien komunitas dan perubahan komposisi jenis gulma pada 3 dan 6 MSA.

\begin{tabular}{|c|c|c|c|c|c|c|c|c|}
\hline \multirow{2}{*}{\multicolumn{2}{|c|}{ Perbandingan }} & \multicolumn{7}{|c|}{$3 \mathrm{MSA}$} \\
\hline & & 1 & 2 & 3 & 4 & 5 & 6 & Nilai Perubahan \\
\hline \multirow{6}{*}{ 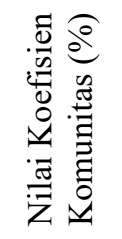 } & 1 & 100 & 70 & 69 & 68 & 42 & 71 & 29 \\
\hline & 2 & & 100 & 52 & 50 & 42 & 51 & 49 \\
\hline & 3 & & & 100 & 58 & 30 & 74 & 26 \\
\hline & 4 & & & & 100 & 47 & 70 & 30 \\
\hline & 5 & & & & & 100 & 31 & 69 \\
\hline & 6 & & & & & & 100 & 0 \\
\hline \multirow{2}{*}{\multicolumn{2}{|c|}{ Perbandingan }} & \multicolumn{7}{|c|}{$6 \mathrm{MSA}$} \\
\hline & & 1 & 2 & 3 & 4 & 5 & 6 & Nilai Perubahan \\
\hline \multirow{6}{*}{ 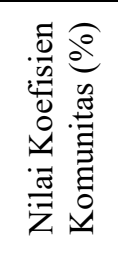 } & 1 & 100 & 74 & 72 & 60 & 50 & 77 & 23 \\
\hline & 2 & & 100 & 68 & 65 & 47 & 72 & 28 \\
\hline & 3 & & & 100 & 59 & 62 & 72 & 28 \\
\hline & 4 & & & & 100 & 63 & 62 & 38 \\
\hline & 5 & & & & & 100 & 43 & 57 \\
\hline & 6 & & & & & & 100 & 0 \\
\hline
\end{tabular}

perbedaan komposisi gulma. Berdasakan penelitian didapatkan nilai kesamaan komposisi gulma pada petak perlakuan herbisida parakuat diklorida disemua taraf dosis dengan tingkat kesamaan antara $50-70 \%$ pada 3 MSA dan 59-74\% pada 6 MSA. Hal ini menunjukkan bahwa antar perlakuan tidak memiliki kesamaan jenis gulma karena nilai kesamaan komunitas $<75 \%$ (Tabel 8). Menurut Tjitrodoedirdjo et al., (1984) apabila terdapat dua komunitas gulma yang dibandingkan memiliki nilai kesamaan komunitas $>75 \%$ menunjukkan bahwa komunitas tersebut memilki kemiripan komposisi jenis gulma. Setelah aplikasi herbisida terjadi perubahan komposisi gulma sekitar 29-49 \% pada 3 MSAdan 23-38\% pada 6 MSA(Tabel 8). Perubahan komposisi jenis gulma akibat aplikasi herbisida parakuat diklorida yang ditunjukkan oleh jumlah jenis gulma yang berbeda pada setiap perlakuan yang dibandingkan dengan kontrol. Menurut Apriadi et al.(2013) penyebab terjadinya perubahan komunitas gulma adalah adanya perbedaan tanggapan jenis gulma terhadap herbisida serta 
kecepatan pertumbuhan gulma yang memungkinkan tumbuhnya spesies-spesies gulma yang sebelumnya tertekan.

\section{Fitotoksisitas Tanaman Kedelai}

Hasil pengamatanmenunjukkan bahwa aplikasi herbisida parakuat diklorida pada dosis $405-810 \mathrm{~g} /$ ha mengindikasikan gejala keracunan ringan, dengan rentang toksisitas antara 5-20\% dengan gejala bercak- bercak seperti terbakar. Hal ini sesuai dengan penelitian Perkasa et al. (2016) yang menyatakan bahwa keracunan dengan skala sedang terjadi pada tanaman kedelai akibat aplikasi herbisida parakuat yang ditandai oleh adanya beberapa tanaman yang daunnya terlihat terbakar.

\section{Pertumbuhan dan Produksi Tanaman Kedelai}

Pada Tabel 10 menunjukkan bahwa pada 3 dan 6 MSA herbisida parakuat diklorida dengan dosis 405 - $810 \mathrm{~g} / \mathrm{ha}$ tidak menekan pertumbuhan tinggi tanaman kedelai. Tinggi tanaman petak kontrol lebih rendah dibandingkan dengan penyiangan manual dan perlakuan dosis herbisida karena tanaman kedelai tidak mampu bersaing dengan gulma dalam memperoleh sarana tumbuh yang ada. Hal tersebut sejalan dengan Nurjannah (2003) yang menyatakan bahwa gulma pada

Tabel 9. Fitotoksisitas tanaman kedelai

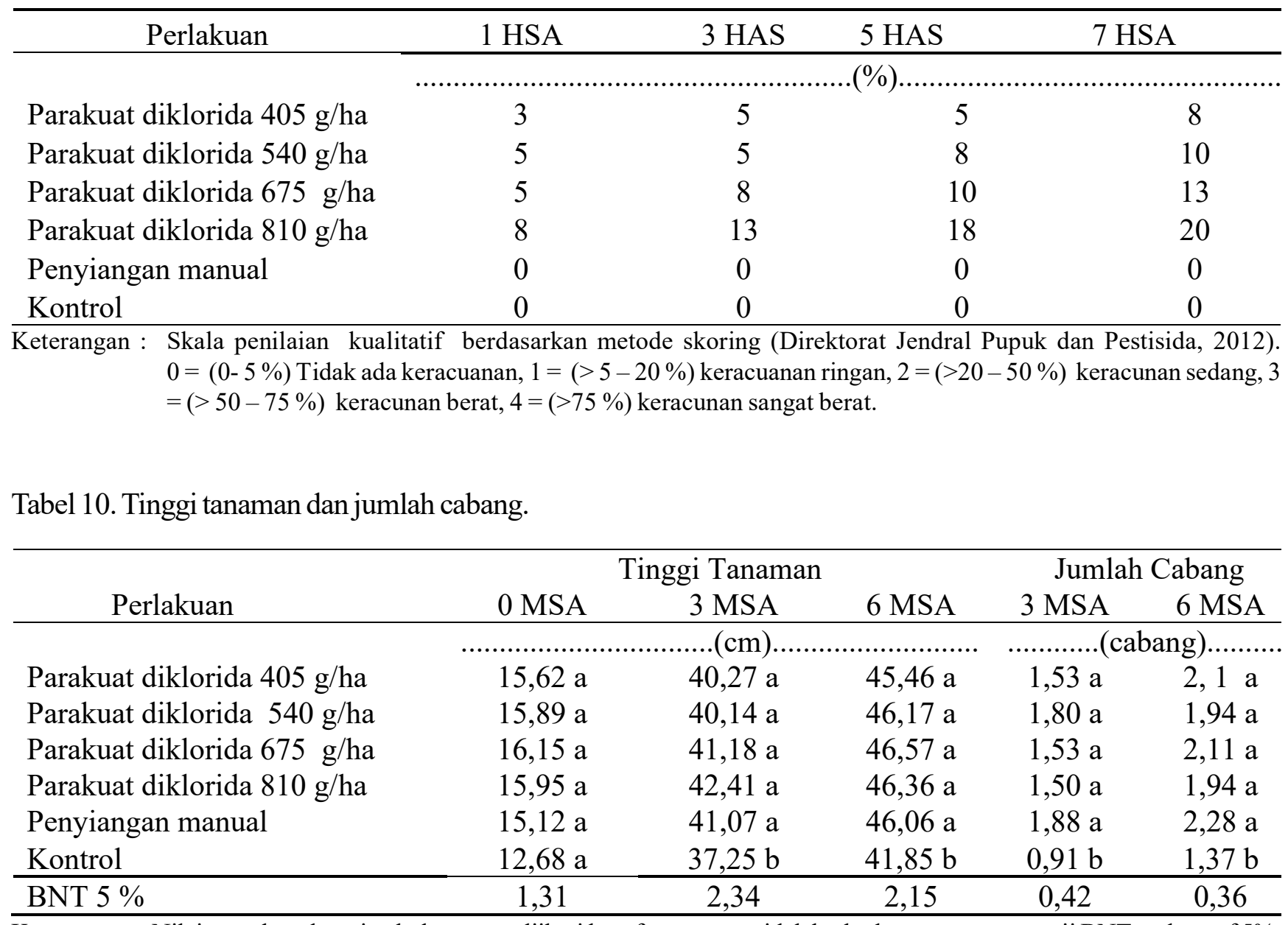

Keterangan : Nilai tengah pada setiap kolom yang diikuti huruf yang sama tidak berbeda nyata menurut uji BNT pada taraf $5 \%$. 
kontrol lebih banyak, sehingga pertumbuhan kedelai lebih rendah dibandingkan perlakuan herbisida. Jumlah cabang kedelai pada 3 dan 6 MSA antar perlakuan herbisida parakuat diklorida dosis $405-810 \mathrm{~g} / \mathrm{ha}$ tidak menghambat pertumbuhan cabang kedelai serta sama dengan perlakuan penyiangan manual.

Tabel (11) menunjukkan bahwa jumlah bunga yang terbentuk pada tanaman kedelai akibat aplikasi herbisida parakuat diklorida pada dosis $405 \mathrm{~g} / \mathrm{ha}$ lebih rendah dari perlakuan dosis herbisida 540-810 g/ha dan penyiangan manual. Pada persentase bunga jadi polong perlakuan herbisida parakuat diklorida pada dosis $540-810 \mathrm{~g} / \mathrm{ha}$ menunjukkan persentase bunga jadi polong yang sama dengan penyiangan manual. Jumlah polong kedelai total menunjukkan bahwa perlakuan herbisida parakuat diklorida pada dosis 540 $-810 \mathrm{~g} / \mathrm{ha}$ menunjukkan jumlah polong total yang sama dengan penyiangan manual karena pada dosis tersebut mampu mengendalikan pertumbuhan gulma dengan baik sehingga kompetisi tanaman dengan gulma lebih rendah. Adnan et al. (2012) menyatakan bahwa gangguan gulma terhadap tanaman selama fase vegetatif yanglebih sedikitakanmeningkatkan pertumbuhankedelai sehingga pembentukan polong menjadi lebih optimal.

Jumlah polong isi pada Tabel 12 menunjukkan bahwa perlakuan herbisida parakuat diklorida pada dosis $405 \mathrm{~g} / \mathrm{ha}$ lebih sedikit dibandingkan dengan dosis $540-810 \mathrm{~g} / \mathrm{ha}$ dan penyiangan manual. Widyatama et al. (2012) menyatakan bahwa gulma yang tumbuh semakin rapat akan semakin memperlambat pertumbuhan dimasa vegetatif tanaman dan mengakibatkan pertumbuhan tanaman yang kurang maksimal, akibatnya ketika tanaman kedelai memasuki fase generatif, terjadi penurunan potensi (penghasil asimilat) dan berakibat rendahnya pertumbuhan organ pemakai seperti polong dan biji. Pada Tabel 12 menunjukkan jumlah polong hampa kedelai pada penyiangan manual menghasilkan jumlah polong kedelai yang lebih sedikit dari perlakuan herbisida. Dosis 405 - $810 \mathrm{~g} /$ ha menunjukkan polong hampa yang sama antar perlakuan tetapi lebih banyak dari penyiangan manual. Menurut Sembodo, (2010) gulma berakibat pada kehilangan hasil dengan cara bersaing dengan tanaman budidaya dimana gulma menjadi inang alternatif

Tabel 11. Jumlah Bunga, Persen Bunga Jadi Polong Dan Jumlah Polong

\begin{tabular}{|c|c|c|c|}
\hline Perlakuan & Bunga/ Tanaman & $\%$ BJP & JPT \\
\hline..$($ kuntum).......... & (Kuntum).. & $\ldots .(\% .(\%) \ldots$ & ......(Polong)... \\
\hline Parakuat diklorida $405 \mathrm{~g} / \mathrm{ha}$ & $50,11 \mathrm{~b}$ & $48,20 \mathrm{ab}$ & $24,18 \mathrm{bc}$ \\
\hline Parakuat diklorida $540 \mathrm{~g} / \mathrm{ha}$ & $52,53 \mathrm{a}$ & 51,46 a & $27,00 \mathrm{ab}$ \\
\hline Parakuat diklorida $675 \mathrm{~g} / \mathrm{ha}$ & $54,28 \mathrm{a}$ & $50,19 \mathrm{ab}$ & $27,22 \mathrm{ab}$ \\
\hline Parakuat diklorida $810 \mathrm{~g} / \mathrm{ha}$ & $52,73 \mathrm{a}$ & 54,45 a & $28,63 \mathrm{a}$ \\
\hline Penyiangan manual & $54,48 \mathrm{a}$ & 52,71 a & $28,84 \mathrm{a}$ \\
\hline Kontrol & $48,77 \mathrm{~b}$ & $43,50 \mathrm{~b}$ & $21,31 \mathrm{c}$ \\
\hline BNT $5 \%$ & 0,16 & 6,95 & 3,69 \\
\hline
\end{tabular}

Keterangan : Nilai tengah pada setiap kolom yang diikuti dengan huruf yang sama tidak berbeda nyata menurut uji BNT pada taraf $5 \%$. BJP:bunga jadi polong, JPT: jumlah polong total. 
Tabel 12. Jumlah Polong Isi dan Jumlah Polong Hampa Tanaman Kedelai, Bobot berangkasan, Bobot 100 Butir, dan Hasil Kedelai Kering Petak Panen.

\begin{tabular}{|c|c|c|c|c|c|c|}
\hline \multirow{2}{*}{ Perlakuan } & \multirow[t]{2}{*}{ JPI } & \multicolumn{2}{|c|}{ Polong Hampa } & \multirow{2}{*}{$\frac{\text { Bobot }}{\text { Berangkasan }}$} & \multirow[b]{2}{*}{100 Butir } & \multirow{2}{*}{$\begin{array}{c}\text { Hasil } \\
\text { Kedelai }\end{array}$} \\
\hline & & Asli & $(\sqrt{ }+0,5)$ & & & \\
\hline & \multicolumn{3}{|c|}{...(Polong).................... } & $\ldots($ gram $) \ldots$ & $\ldots($ gram $) \ldots$ & $\ldots\left(\mathrm{g} / 4 \mathrm{~m}^{2}\right)$. \\
\hline Parakuat diklorida $405 \mathrm{~g} / \mathrm{ha}$ & $22,85 \mathrm{c}$ & 1,35 & $1,34 \mathrm{ab}$ & $2,18 \mathrm{ab}$ & $13,45 \mathrm{a}$ & $304,70 \mathrm{c}$ \\
\hline Parakuat diklorida $540 \mathrm{~g} / \mathrm{ha}$ & $25,81 \mathrm{ab}$ & 1,18 & $1,29 \mathrm{~b}$ & $2,27 \mathrm{a}$ & $13,74 \mathrm{a}$ & $369,92 \mathrm{~b}$ \\
\hline Parakuat diklorida $675 \mathrm{~g} / \mathrm{ha}$ & $25,49 \mathrm{ab}$ & 1,53 & $1,42 \mathrm{ab}$ & $2,35 \mathrm{a}$ & $13,73 \mathrm{a}$ & $317,28 \mathrm{~b}$ \\
\hline Parakuat diklorida $810 \mathrm{~g} / \mathrm{ha}$ & 27,39 a & 1,24 & $1,30 \mathrm{~b}$ & $2,38 \mathrm{a}$ & $14,33 \mathrm{a}$ & $404,85 \mathrm{ab}$ \\
\hline Penyiangan manual & 28,20 a & 0,64 & $1,06 \mathrm{c}$ & $2,42 \mathrm{a}$ & $13,70 \mathrm{a}$ & $438,94 \mathrm{a}$ \\
\hline Kontrol & $19,20 \mathrm{c}$ & 1,9 & $1,54 \mathrm{a}$ & $1,96 \mathrm{~b}$ & $13,34 \mathrm{a}$ & $286,98 \mathrm{c}$ \\
\hline BNT $5 \%$ & 3,66 & & 0,21 & 0,23 & 1,01 & 1,49 \\
\hline
\end{tabular}

Keterangan : Nilai tengah pada setiap kolom yang diikuti huruf yang sama tidak berbeda nyata menurut uji BNT pada taraf $5 \%$.

dari hama dan penyakit.

Pada Tabel 12 menunjukkan bahwa perlakuan herbisida parakuat diklorida 405 - $810 \mathrm{~g} / \mathrm{ha}$ dan penyiangan manual menunjukkan bobot kering bangkasan yang lebih tinggi dari perlakuan kontrol. Hal ini terjadi akibat adanya persaingan antara tanaman kedelai dengan gulma terutama gulma daun lebar dan gulma rumput yang mendominasi pada petak kontrol. Bobot biji kedelai 100 butir pada Tabel 12 menunjukkan bahwa dosis herbisida tidak berpengaruh terhadap bobot biji kedelai. Sutoro dan Setyowati (2008) menyatakan bahwa bobot biji berhubungan dengan kapasitas source dan sink. Apabila kapasitas source besar namun kapasitas sink rendah maka akan menghasilkan bobot biji yang rendah dan sebaliknya. Hasil kedelai kering perpetak panen (Tabel 12) menunjukkan bahwa dosis herbisida parakuat $810 \mathrm{~g} /$ ha menghasilkan kedelai petak panen sama dengan penyiangan manual karena pada dosis perlakuan herbisida $810 \mathrm{~g} /$ ha efektif mengendalikan gulma dilahan kedelai pada 3 dan 6 MSA, hal ini sejalan dengan Adnan (2012) hal ini terjadi karena gulmapada perlakuan tersebut terkendali dengan baik sejak awal pertumbuhan tanaman.

\section{KESIMPULAN}

Herbisida parakuat diklorida dosis 405-810 $\mathrm{g} /$ ha efektif mengendalikan gulma total, gulma golongan daun lebar, gulma golongan rumput serta gulma dominan (Croton hirtus, Mimosa invisa, Rottboellia exaltata, dan Synedrella nodiflora)di areal tanaman kedelai hingga 6 MSA. Herbisida parakuat diklorida menyebabkan perubahan komposisi jenis gulma antara $29-49 \%$ pada 3 MSA dan 23-38 \% pada 6 MSA.

Aplikasi herbisida parakuat diklorida dosis 405$810 \mathrm{~g} /$ ha menyebabkan fitotoksisitas dalam skala ringan dengan rentang toksisitas 5-20\%, dosis 405-810 g/ha tidakmenghambat pertumbuhan dan produksi kedelailebih rendah pada perlakuan herbisida dosis $405-675 \mathrm{~g} / \mathrm{ha}$.

\section{DAFTAR PUSTAKA}

Adnan, H dan Manfaizah. 2012. Aplikasi Beberapa Dosis Herbisida Glifosat dan Parakuat Diklorida pada Sistem Tanpa Olah Tanah (TOT) serta Pengaruhnya terhadap Sifat Kimia Tanah, Karakteristik Gulma dan Hasil Kedelai. Jurnal Agrista. 16(3):135-145.

Apriadi, W., D. R. J. Sembodo, dan H. Susanto. 2013. Efikasi herbisida 2,4 D terhadap Gulma pada 
Tanaman Padi Sawah (Oryza sativa.). J. Agrotek Tropika. 10 (2):79-84.

Badan Pusat Statistik. 2015. Pertanian dan Pertambangan : Perkebunan. https:// www.bps.go.id/linkTableDinamis/vview/id/ 871. Diakses pada 18 November 2018.

Direktorat Jendral Pupuk dan Pestisida. 2012. Metode Standar Pengujian Efikasi Herbisida. Direktorat Sarana dan Prasarana Pertanian. Jakarta. $229 \mathrm{hlm}$.

Nurjannah, U. 2003. Pengaruh Dosis Herbisida Glifosat dan 2,4-D terhadap Pergeseran Gulma dan Tanaman Kedelai Tanpa Olah Tanah. Jurnal Ilmu-Ilmu Pertanian Indonesia. 5(1):27-33.

Perkasa,A. Y., M. Ghulamahdi, dan D. Guntoro. 2016. Penggunaan Herbisida untuk Pengendalian Gulma pada Budidaya Kedelai Jenuh Air di Lahan Pasang Surut. Jurnal Penelitian Pertanian Tanaman Pangan.35(1):64-68.
Sarbino dan E. Syahputra. 2012. Keefektifan Parakuat Diklorida Sebagai Herbisida untuk Persiapan Tanam Padi Tanpa Olah Tanah di Lahan Pasang Surut. Jurnal Perkebunan \& Lahan Tropika. 2(1):21-22.

Sembodo, D.R.J. 2010. Gulma dan Pengelolaannya. Graha Ilmu. Yogyakarta. $166 \mathrm{hlm}$.

Sutoro, N.D., dan M. Setyowati. 2008. Hubungan sifat morfologis tanaman dengan hasil kedelai. Jurnal Penelitian Pertanian Tanaman Pangan. 23 (3):185-190.

Umiyati, U., D. Widayat., D. Kurniadie., dan K. Aris. 2019. Respon Pertumbuhan Gulma dan Hasil Tanaman Jagung tehadap Herbisida 276 G/L Pada Sistem TOT. J. Agrotech Reserch. 3(1):18-22. 